Prepared in cooperation with the U.S. Army Corps of Engineers, Chicago District

\title{
Lake Michigan Diversion Accounting Land Cover Change Estimation by Use of the National Land Cover Dataset and Raingage Network Partitioning Analysis
}

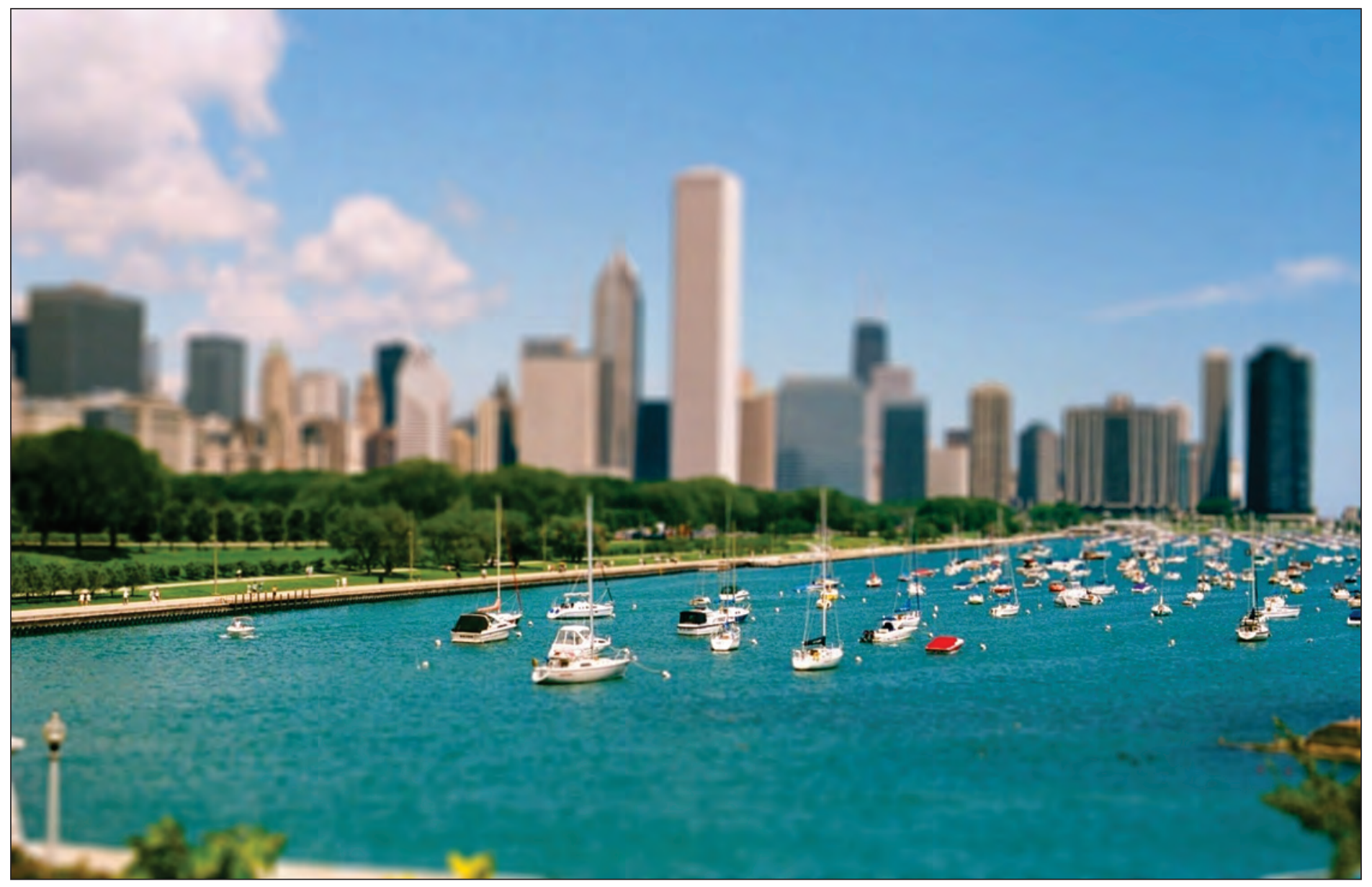

Open-File Report 2014-1258 
Cover: Chicago skyline. (Photograph by Jennifer B. Sharpe) 


\section{Lake Michigan Diversion Accounting Land Cover Change Estimation by Use of the National Land Cover Dataset and Raingage Network Partitioning Analysis}

By Jennifer B. Sharpe and David T. Soong

Prepared in cooperation with the U.S. Army Corps of Engineers, Chicago District

Open-File Report 2014-1258 


\title{
U.S. Department of the Interior SALLY JEWELL, Secretary
}

\section{U.S. Geological Survey Suzette M. Kimball, Acting Director}

\author{
U.S. Geological Survey, Reston, Virginia: 2015
}

For more information on the USGS - the Federal source for science about the Earth, its natural and living resources, natural hazards, and the environment, visit http://www.usgs.gov or call 1-888-ASK-USGS.

For an overview of USGS information products, including maps, imagery, and publications, visit http://www.usgs.gov/pubprod.

To order this and other USGS information products, visit http://store.usgs.gov.

Any use of trade, firm, or product names is for descriptive purposes only and does not imply endorsement by the U.S. Government.

Although this information product, for the most part, is in the public domain, it also may contain copyrighted materials as noted in the text. Permission to reproduce copyrighted items must be secured from the copyright owner.

Suggested citation:

Sharpe, J.B., and Soong, D.T., 2015, Lake Michigan Diversion Accounting land cover change estimation by use of the National Land Cover Dataset and raingage network partitioning analysis: U.S. Geological Survey Open-File Report 2014-1258, 12 p., http://dx.doi.org/10.3133/ofr20141258.

ISSN 2331-1258 (online) 


\section{Contents}

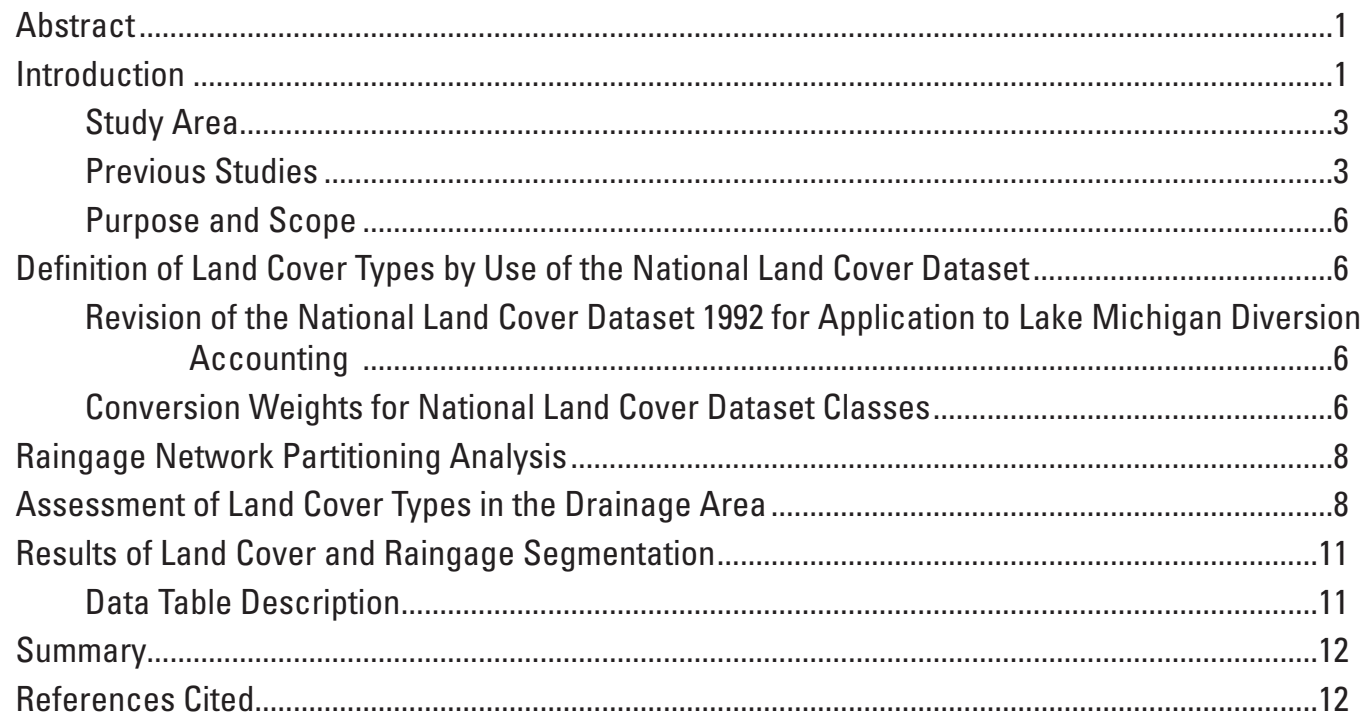

\section{Figures}

1. Map showing location of diverted Lake Michigan watershed, special contributing areas (SCAs), upstream gaged basins, and ungaged basins, in northeastern Illinois

2. Map showing Lake Michigan Diversion Accounting special contributing areas, Cook County, Illinois .

3. Map showing location of the Lake Michigan Diversion Area raingage networks, northeastern Illinois.

\section{Tables}

1. Areas comprising the Lake Michigan Diversion Accounting program

2. Impervious and grass land cover conversion weights from RUST Environment \& Infrastructure and the 1997 Soil Conservation Service TR-55...

3. Weights applied to National Land Cover Dataset classes for conversion to impervious, grass, and forest land classes.

4. Total basin area and percentage of impervious, grass, and forest areas determined by RUST Environment and Infrastructure, 1997 Soil Conservation Service TR-55 and National Land Cover Dataset (NLCD) 92 data.

5. National Land Cover Datasets $92,01,06$, and 11 percentages of impervious, grass, and forest areas for ungaged, gaged, and upstream basins ...

Tables 5-20 are presented in a Microsoft Excel file available at http://dx.doi.org/10.3133/ofr20141258. 


\section{Conversion Factors}

Inch-pound to International System of Units (SI)

\begin{tabular}{|c|c|c|}
\hline Multiply & By & To obtain \\
\hline \multicolumn{3}{|c|}{ Length } \\
\hline foot $(\mathrm{ft})$ & 0.3048 & meter $(\mathrm{m})$ \\
\hline mile (mi) & 1.609 & kilometer (km) \\
\hline \multicolumn{3}{|c|}{ Area } \\
\hline acre & 4,047 & square meter $\left(\mathrm{m}^{2}\right)$ \\
\hline acre & 0.004047 & square kilometer $\left(\mathrm{km}^{2}\right)$ \\
\hline square foot $\left(\mathrm{ft}^{2}\right)$ & 0.09290 & square meter $\left(\mathrm{m}^{2}\right)$ \\
\hline square mile $\left(\mathrm{mi}^{2}\right)$ & 2.590 & square kilometer $\left(\mathrm{km}^{2}\right)$ \\
\hline
\end{tabular}

International System of Units to inch-pound

\begin{tabular}{|c|c|c|}
\hline Multiply & By & To obtain \\
\hline \multicolumn{3}{|c|}{ Length } \\
\hline meter (m) & 3.281 & foot $(\mathrm{ft})$ \\
\hline \multicolumn{3}{|c|}{ Area } \\
\hline square meter (m2) & 0.0002471 & acre \\
\hline square meter $(\mathrm{m} 2)$ & 10.76 & square foot (ft2) \\
\hline
\end{tabular}

\section{Datums}

Vertical coordinate information is referenced to the North American Vertical Datum of 1988 (NAVD).

Horizontal coordinate information is referenced to the North American Datum of 1983 (NAD 83). Altitude, as used in this report, refers to distance above the vertical datum. 


\title{
Lake Michigan Diversion Accounting Land Cover Change Estimation by Use of the National Land Cover Dataset and Raingage Network Partitioning Analysis
}

\author{
By Jennifer B. Sharpe and David T. Soong
}

\begin{abstract}
The U.S. Army Corps of Engineers (USACE), Chicago District, is responsible for monitoring and computation of the quantity of Lake Michigan water diverted by the State of Illinois. As part of this effort, the USACE uses the Hydrological Simulation Program-FORTRAN (HSPF) with measured meteorological data inputs to estimate runoff from the Lake Michigan diversion special contributing areas (SCAs), the North Branch Chicago River above Niles and the Little Calumet River above South Holland gaged basins, and the Lower Des Plaines and the Calumet ungaged that historically drained to Lake Michigan. These simulated runoffs are used for estimating the total runoff component from the diverted Lake Michigan watershed, which is accountable to the total diversion by the State of Illinois. The runoff is simulated from three interpreted land cover types in the HSPF models: impervious, grass, and forest. The three land cover data types currently in use were derived from aerial photographs acquired in the early 1990s.

This study used the National Land Cover Dataset (NLCD) and developed an automated process for determining the area of the three land cover types, thereby allowing faster updating of future models, and for evaluating land cover changes by use of historical NLCD datasets. The study also carried out a raingage partitioning analysis so that the segmentation of land cover and rainfall in each modeled unit is directly applicable to the HSPF modeling. Historical and existing impervious, grass, and forest land acreages partitioned by percentages covered by two sets of raingages for the Lake Michigan diversion SCAs, gaged basins, and ungaged basins are presented.
\end{abstract}

\section{Introduction}

The U.S. Army Corps of Engineers (USACE) is responsible for monitoring the measurement and the computation of the quantity of Lake Michigan water that is diverted by the
State of Illinois. The USACE diversion accounting system covers an area where river water had historically flowed into Lake Michigan. In this area, known as the diverted Lake Michigan watershed (fig. 1), river water had originally entered Lake Michigan through the Chicago River, but the water has been diverted to the Illinois River, and eventually the Mississippi River, through various diversion projects since the 1900s (Hill, 2007). Construction of the Chicago Sanitary and Ship Canal (CSSC), the Calumet-Sag Channel, and the North Shore Channel, along with dams at outlets from Lake Michigan, rerouted river flow to the southwest, where it eventually joins the Des Plaines River downstream of Lockport. The diverted Lake Michigan watershed is approximately 673 square miles $\left(\mathrm{mi}^{2}\right)$ in size (USACE, 2004).

Runoff from the diverted Lake Michigan watershed is an important element in the hydrologic budget of the Lake Michigan Diversion Accounting (LMDA) system. Accounting for runoff is accomplished by using a combination of recorded streamflow and runoff simulated with recorded rainfall by use of the Hydrological Simulation Program-FORTRAN (HSPF). Streamflow is measured at several U.S. Geological Survey (USGS) streamflow-gaging stations (fig. 1), including those at the Chicago Sanitary and Ship Canal at Lemont (USGS streamgage 05536890), the North Branch Chicago River at Niles (USGS streamgage 05536000), and the Little Calumet River at South Holland (USGS streamgage 05536290). The Chicago Sanitary and Ship Canal at Lemont gage replaced the original gage used in the LMDA, the Chicago Sanitary and Ship Canal at Romeoville (USGS streamgage 05536995). Most of the diverted watershed is ungaged or poorly gaged because the combined sewer overflow is part of the flow sources to the gage. In this report, basins where streamflow is measured at streamflow-gaging stations are referred to as "gaged basins," and those that lack streamflow-gaging stations are referred to as "ungaged basins." 


\section{Lake Michigan Diversion Accounting Land Cover Change Estimation}

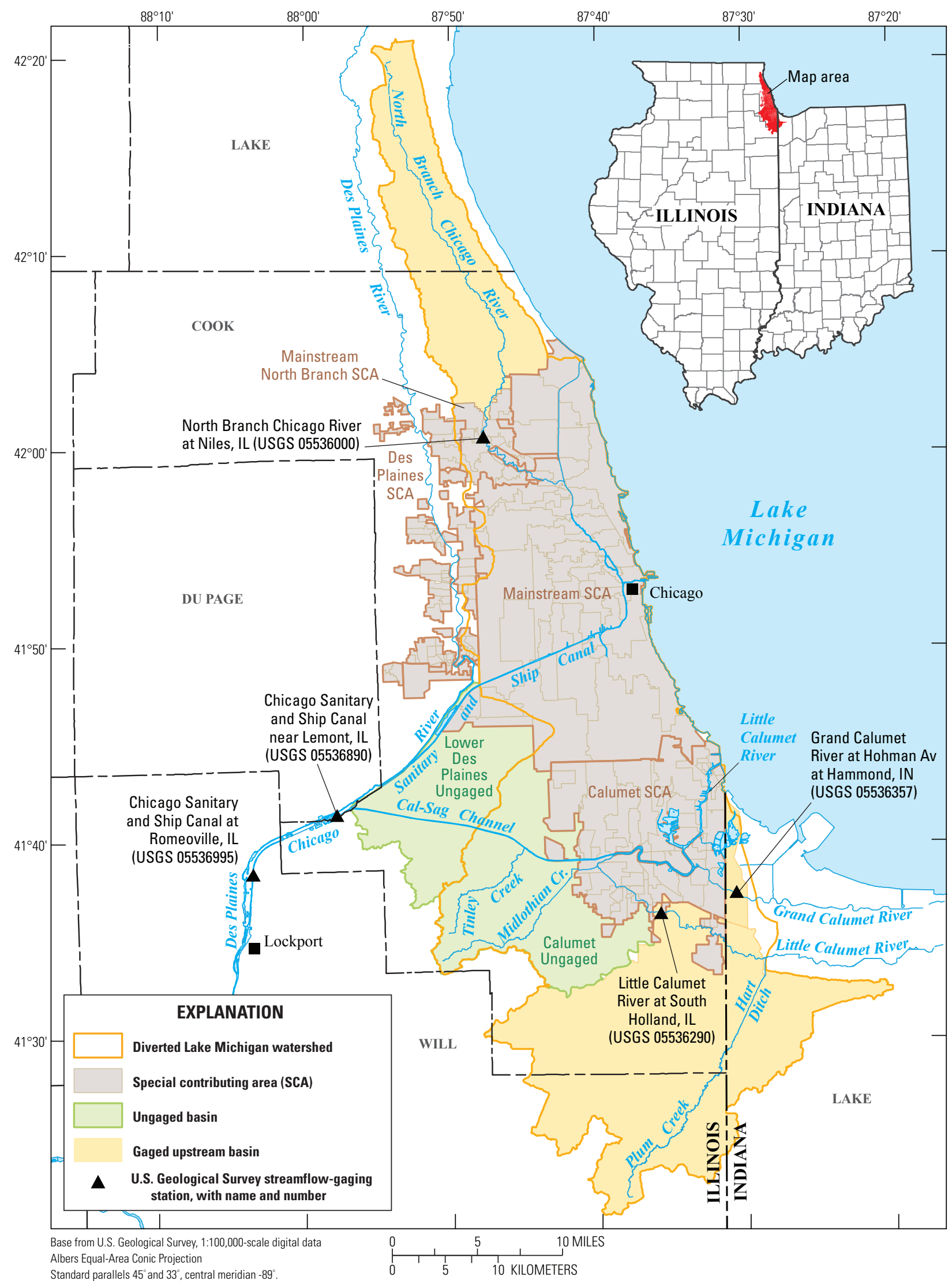

Figure 1. Location of diverted Lake Michigan watershed, special contributing areas (SCAs), upstream gaged basins, and ungaged basins, in northeastern Illinois. 


\section{Study Area}

The diversion accounting system consists of two gaged upstream basins, the ungaged sewered area, and the ungaged Calumet River (fig. 1). The two gaged upstream basins are: the North Branch Chicago River at Niles (USGS streamgage 05536000) and the Little Calumet River at South Holland (USGS streamgage 05536290). A portion of the diverted Lake Michigan watershed is in an area that cannot be accurately gaged because the flow is drained by sewers. These areas, known as special contributing areas (SCAs), are sewered watersheds that drain to the Metropolitan Water Reclamation District of Greater Chicago (MWRDGC) Tunnel and Reservoir Plan (TARP) system. The TARP system acts as a holding reservoir for stormwater runoff and sewage, which is then treated at water reclamation plants as capacity becomes available. Once treated, water is discharged into waterways, where it can be accounted for by USGS gages. These SCA areas must be modeled by use of recorded rainfall and modeled land cover to determine runoff values.

A geographic information system (GIS) shapefile of SCAs was provided for the study by the USACE (T.Y. Su, private commun., June 2011). The shapefile was originally developed in AutoCAD by RUST Environment \& Infrastructure by use of electric planimeters to delineate the SCA boundaries. There are about 200 SCAs ranging in size from about 8.5 acres to over 14,000 acres (fig. 2).

An SCA is normally coded by the TARP system to which it drains (table 1) except for a few SCAs close to the divide of Lake Michigan and the Des Plaines River watershed near the downstream end of the mainstream TARP system. For example, SCAs M53, DP53, DP54, DP55, DP 56, and DP 65 comprise an area of about $4 \mathrm{mi}^{2}$ that is in the Des Plaines River watershed but that is served by Sewer System 13A, part of the mainstream TARP system (USACE, 1981). As another example, SCAs M48DP, M49BDP, M55-1 and M55-2 are in the lower Des Plaines River watershed (south of the CSSC), but their combined sewer drains to the mainstream TARP system as well. With this understanding, the drainage areas of M53, M48DP, M49BDP, M55-1, and M55-2 are not counted as part of the total drainage area of the LMDA watershed, but their drainage areas are counted when the mainstream (code M or MN) TARP system is modeled.

By following the LMDA diversion accounting procedure, the measured flow on the CSSC at USGS streamgage 05536890 (fig. 1) was found to include more runoff and streamflow than would historically be included in the diverted Lake Michigan watershed. The Des Plaines SCA and the Lower Des Plaines ungaged basin naturally fall outside of the diverted watershed, and runoff volumes calculated for those areas must be subtracted from the total measured flow at the Lemont gage (Jim Duncker, written comm., September 2014). In this report, the Des Plaines SCA and the ungaged Lower Des Plaines basin are included in the analysis but are not counted in the LMDA watershed. The LMDA watershed includes the North Branch Chicago River watershed above
Niles, the Mainstream SCA, the Mainstream North Branch SCA, the Calumet SCA, the ungaged Calumet, and the gaged Little Calumet River at South Holland, which includes the Grand Calumet River (fig. 1).

\section{Previous Studies}

Surface runoff volumes from the diverted Lake Michigan watershed have been estimated with the HSPF program (Donigian and others, 1984). Various physical factors can affect the watershed model setup and, therefore, the performance of HSPF in runoff simulation. These factors include the area of land covers determined (in acres), distributions of raingage data, and changes in land covers. Evaluation of their accuracy is part of the effort to maintain the predictive accuracy of the diversion accounting program.

Within HSPF, the response of the land phase of the hydrologic cycle is simulated using land segments; a segment is defined as an area with uniform hydrologic characteristics. Two types of land segments are defined: 1) pervious, a land segment that has the capacity to allow enough infiltration to influence the water budget, and 2) impervious, a land segment in which little or no infiltration occurs. The pervious land is represented by grass and forest lands in LMDA modeling.

The area of impervious land segments represented in modeling should be the "effective" impervious area (EIA), rather than the total or mapped impervious area of the watershed of interest. The EIA is that portion of the total impervious area that is directly connected to the drainage system (for example, storm drains, streams, rivers, lakes), including rooftops that drain directly to driveways or storm drains. These areas are considered hydraulically connected. Impervious runoff that drains first to pervious areas can infiltrate and should not be included in the impervious simulation. In most watersheds, the EIA is less than the total impervious area, especially in less dense residential areas. Conversely, in highly urbanized areas, the EIA and total impervious areas are often very similar (Donigian and others 1984). Computing EIA from various land surfaces has been analyzed by the Soil Conservation Service (SCS) (SCS, 1986); see table 2 for details.

During a study in 1993, RUST Environment \& Infrastructure (RUST, 1993; hereafter referred to as "RUST") used electronic planimeters to delineate the SCA boundaries into 10 land use categories. The EIA from the 10 land use categories was calculated by using weights, which also are listed in table 2. All non-EIA acreages were assigned to "grass," because forest acreages were considered insignificant in the SCA basins in the diverted Lake Michigan watershed. In table 2, the conversion factors for the Low Density Residential, Medium Density Residential, High Density Residential, and Multifamily and High Rise Residential lands differ from the original SCS factors. The RUST categories also include Highway Corridor With/Without Grass Median categories, which SCS did not include. A detailed review of the previous EIA percentages (RUST, 1993) that were applied in the rainfall-runoff 


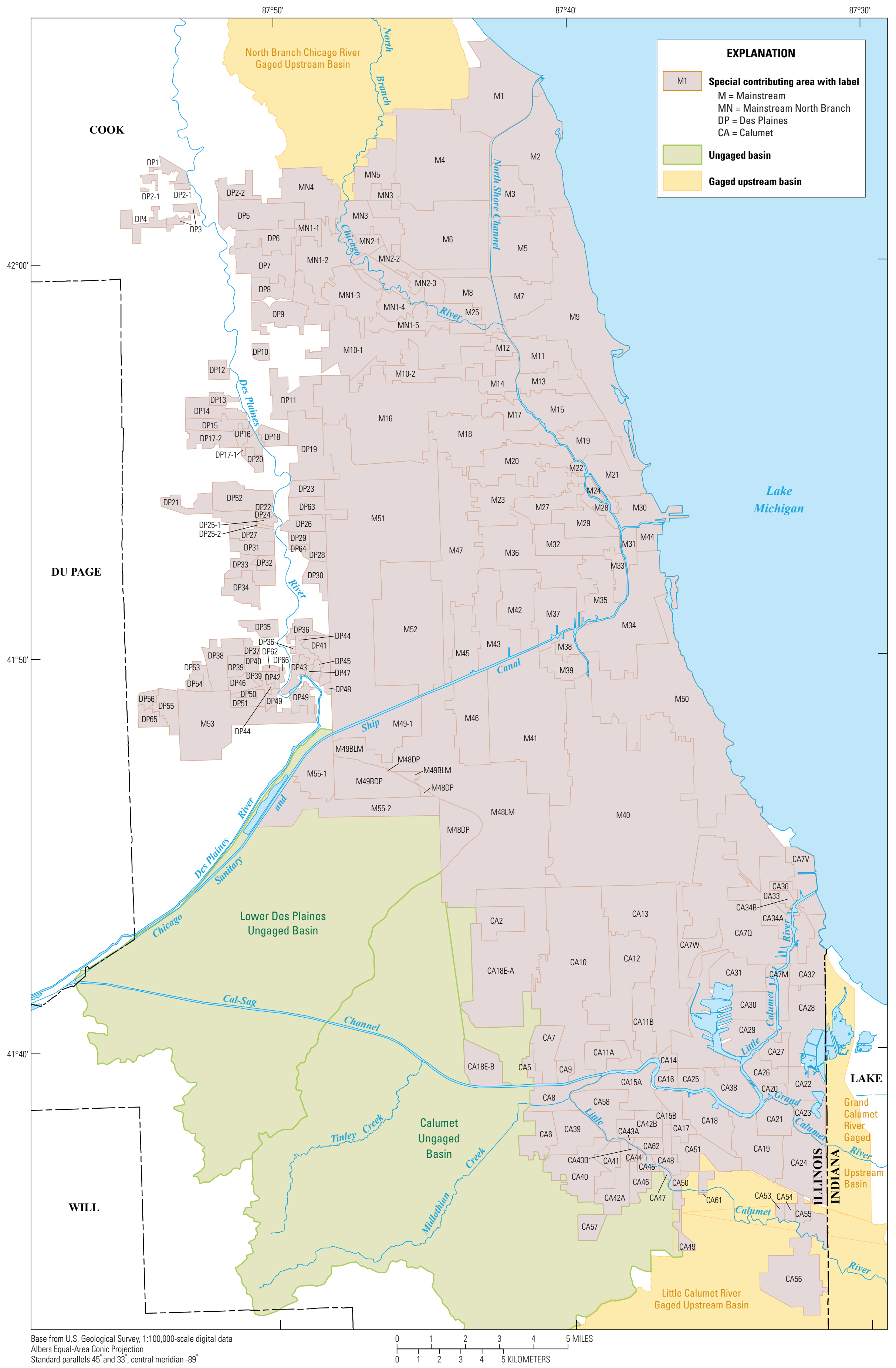


Table 1. Areas comprising the Lake Michigan Diversion Accounting program.

[SCA, special contributing area; TARP, Tunnel and Reservoir Plan; - , not applicable]

\begin{tabular}{lcc}
\hline \multicolumn{1}{c}{ Accounting area with abbreviation } & $\begin{array}{c}\text { Area } \\
\text { (square miles) }\end{array}$ & $\begin{array}{c}\text { Number of SCA in } \\
\text { accounting area }\end{array}$ \\
\hline Mainstream TARP (M) SCA & 204.43 & 58 \\
Mainstream North Branch TARP (MN) SCA & 15.19 & 11 \\
Des Plaines (DP) SCA & 32.34 & 64 \\
Calumet TARP (CA) SCA & 88.74 & 65 \\
Lower Des Plaines Ungaged & 57.95 & - \\
Calumet Ungaged & 84.22 & - \\
North Branch Chicago River Gaged & 92.93 & - \\
Little Calumet River & 188.32 & - \\
Grand Calumet River Gaged & 6.89 & - \\
\hline
\end{tabular}

Table 2. Impervious and grass land cover conversion weights from RUST Environment \& Infrastructure (RUST, 1993) and the 1997 Soil Conservation Service TR-55 (U.S. Army Corps of Engineers, 2001).

[RUST Environment \& Infrastructure: RUST; 1997 Soil Conservation Service TR-55: SCS-1997; Highlighted portions show where RUST weights differ from SCS-1997]

\begin{tabular}{lcccc}
\hline \multirow{2}{*}{ RUST land use category } & \multicolumn{2}{c}{ RUST weights } & \multicolumn{2}{c}{ SCS TR-55 ('1997) } \\
\cline { 2 - 5 } & Impervious & Grass & Impervious & Grass \\
\hline Open Water & 1 & 0 & 1 & 0 \\
Open Space / Park & 0.05 & 0.95 & 0.05 & 0.95 \\
Low Density Residential & 0.19 & 0.81 & 0.2 & 0.8 \\
Medium Density Residential & 0.4 & 0.6 & 0.25 & 0.75 \\
High Density Residential & 0.56 & 0.44 & 0.38 & 0.62 \\
Multifamily and High Rise & 0.7 & 0.3 & 0.65 & 0.35 \\
Industrial & 0.72 & 0.28 & 0.72 & 0.28 \\
Commercial & 0.85 & 0.15 & 0.85 & 0.15 \\
Highway Corridor with Grass Median & 0.5 & 0.5 & & \\
Highway Corridor with No Grass Median & 0.8 & 0.2 & & \\
\hline
\end{tabular}

${ }^{1}$ See U.S. Army Corps of Engineers (2001). 
modeling was conducted by the USACE (USACE, 2001). Based on that analysis, it was determined that the EIA areas delineated previously were overestimated. The EIA designations were revised (USACE, 2001) based on values presented in the SCS runoff curve number $(\mathrm{CN})$ table for urban areas (table 2-2a on p. 2-5 of SCS, 1986), which contains average hydraulically connected impervious values (in percent) for eight urban land use types (see table 2). These ratios are: Mainstream TARP: 0.94; Mainstream North Branch TARP: 0.89; Des Plaines TARP: 0.87; Calumet TARP: 0.93; Ungaged Lower Des Plaines: 0.90; and Ungaged Calumet: 0.89. Any reductions in impervious weights were added to the grass land weights. The results of this conversion have been documented in the Lake Michigan Diversion Accounting report for water year 1996 (USACE, 2001) and will be discussed in a later section.

In 2008, the USGS in collaboration with the USACEChicago District assessed the accuracy of simulated runoff volumes from the gaged Tinley Creek and Midlothian Creek watersheds. During that study, the land cover types were delineated from a 2005 USGS digital color orthophotograph (URL: http://nationalmap.gov/viewer.html), and the SCS EIA factors were confirmed to be reasonable for converting the land use types to LMDA land cover classes. In 2012, a follow-up study by the USGS and the USACE assessed the accuracy of simulated runoff volumes from nine gaged watersheds in and adjacent to the diverted Lake Michigan watershed by using the 2006 NLCD. With the successful conversion from NLCD to LMDA land cover classes, an opportunity is presented to document the changes in land cover over the years.

\section{Purpose and Scope}

The purpose of this report is to document the data, procedures, and results of partitioning the special contributing areas, gaged upstream basins, and ungaged basins into land cover and raingage combinations for HSPF model applications. The land cover and raingage partition analysis included the use of four NLCD (1992, 2001, 2006, and 2011) and two raingage networks (inception in 1989 and current as of 2013). The four land cover and raingage partitions and the changes between each combination are documented in this report.

\section{Definition of Land Cover Types by Use of the National Land Cover Dataset}

The original LMDA modeling used land cover derived from aerial photography. RUST manually delineated basin boundaries on the photography and classified those areas by using 10 categories (see table 2). Because categorizing photography is a labor- and time-intensive undertaking, the NLCD was chosen to update the land cover for the basins used in the model.
The NLCD is a Landsat-based, 30-meter (m) resolution land cover dataset for the entire United States developed by the Multi-Resolution Land Characteristics (MRLC) Consortium, which is led by the USGS. Datasets have been developed for circa 1992 (NLCD92), 2001 (NLCD01), 2006 (NLCD06), and 2011 (NLCD11). NLCD01, NLCD06, and NLCD11 all share a common classification (table 3); however, NLCD92 differs slightly in its classification. Therefore, NLCD01, 06, and 11 were used without revision, but NLCD92 was revised to match the other years.

\section{Revision of the National Land Cover Dataset 1992 for Application to Lake Michigan Diversion Accounting}

Various classes of NLCD92 differ from those for NLCD01, 06, and 11. NLCD92 lacks classes 24, 52, 90, and 95 , but it has several classes not included in the later NLCD data, including classes 32, 83, 91, and 92. Shrub/Scrub was changed from class 51 in NLCD92 to class 52 in later datasets. This mismatch in class numbers and definitions caused discrepancies in area values and made comparisons of NLCD92 results to those from the other years difficult.

A visual inspection of NLCD92 classes demonstrated that class 85 (Urban/Recreational Grasses) shared a similar footprint to that of class 21 (Developed, Open Space) in the NLCD01/06/11 datasets. To test this relationship for NLCD92, class 85 was reclassified as class 21 . Visual inspection also indicated that NLCD92 classes 21 (Low Intensity Residential), 22 (High Intensity Residential), and 23 (Commercial/Industrial/Transportation) strongly matched classes 22 (Developed, Low Intensity), 23 (Developed, Medium Intensity), and 24 (Developed, High Intensity) in NLCD01/06/11. To test this relationship for NLCD92, classes 21-23 were reclassified as classes 22-24. The reclassified NLCD92 data were compared to later datasets and found to match well, and it was determined that the reclassified NLCD92 would be used.

\section{Conversion Weights for National Land Cover Dataset Classes}

The 15 NLCD land cover classes were converted to the 3 LMDA land cover types by use of a weight matrix (table 3 ) developed for a 2008 analysis (U.S. Army Corps of Engineers, 2014). After the weight was applied to each class, the resulting areas were combined for the final impervious, grass, or forest land area. Note that forest land was considered nonexistent in the SCA. The effects of having or not having forest land will be evaluated in a section below.

An ESRI ARCGIS ArcMap toolbox script named "Feature Weights to Table," developed by the USGS Enterprise GIS group, was used to parse the NLCD data for each SCA zone. This provided the total area in square meters $\left(\mathrm{m}^{2)}\right.$ for 
each land cover type in each SCA zone. A script was then written to convert each land cover type into its portion of impervious, grass, and forest. These converted values were then totaled to provide a single value for impervious, grass, and forest for each SCA zone. Values were converted from square meters to acres and percentage of total area. For example, SCA zone M37 has an area of $1.868 \mathrm{mi}^{2}$ or $1,195.57$ acres, and within this zone are NLCD11 classes for open water $(109,800$ $\left.\mathrm{m}^{2}\right)$, open space $\left(23,400 \mathrm{~m}^{2}\right)$, low intensity developed $(75,600$ $\left.\mathrm{m}^{2}\right)$, medium intensity developed $\left(833,400 \mathrm{~m}^{2}\right)$, and high intensity developed $\left(3,786,300 \mathrm{~m}^{2}\right)$. To calculate the impervious, grass, and forest land acres, the following equations would be used:

$$
\begin{gathered}
\text { Impervious acres }=(109800 * 1)+(23400 * 0.19)+ \\
(75600 * 0.37)+(833400 * 0.45)+(3786300 * 0.95)= \\
4,114,233 \mathrm{~m}^{2}=1,016.64 \mathrm{ac} \\
\text { Grass land acres }=(109800 * 0)+(23400 * 0.81)+ \\
(75600 * 0.615)+(833400 * 0.51)+(3786300 * 0.05)= \\
679,797 \mathrm{~m}^{2}=167.98 \mathrm{ac}
\end{gathered}
$$

Forest land acres $=(109800 * 0)+(23400 * 0)+$ $(75600 * 0.015)+(833400 * 0.04)+(3786300 * 0)=$ $34,470 \mathrm{~m}^{2}=8.52 \mathrm{ac}$
Note the total calculated area of the three land covers is $1,193.14$ acres, which is 2.43 acres less than the SCA area of 1,195.57 acres. This example illustrates that there may be a minor difference in calculated areas (in acres) between that computed from the GIS shapefile provided and from the conversion weights calculation. Calculated area is based on a $30-\mathrm{m}^{2}$ pixel size. Only those pixels with centers that fall within the SCA area are included in the calculation for that area. Therefore, total calculated areas are always based on a uniform area that is divisible by 900 , and thus the total calculated areas will probably not match the GIS area. The conversion weights themselves also introduce differences, because their precision was kept to two digits after the decimal. The final result shows that the area differences are very small and may be considered negligible.

The resulting NLCD classes and LMDA land cover types for the LMDA watershed, the ungaged Lower Des Plaines basin, and the Des Plaines SCA are presented in tables 7-10 and tables 12 and 13 for the four NLCD datasets, respectively. These tables are in the Excel file "Tables_5 through_20.xlsx" in the directory of downloadable files at http://dx.doi.org/ 10.3133/ofr20141258.

Table 3. Weights applied to National Land Cover Dataset classes for conversion to impervious, grass, and forest land classes.

\begin{tabular}{lcll}
\hline \multicolumn{1}{c}{$\begin{array}{c}\text { National Land Cover Dataset class } \\
\text { description and number }\end{array}$} & $\begin{array}{c}\text { Impervious } \\
\text { weight }\end{array}$ & $\begin{array}{c}\text { Grass } \\
\text { weight }\end{array}$ & $\begin{array}{c}\text { Forest } \\
\text { weight }\end{array}$ \\
\hline Open Water (11) & 1 & 0 & 0 \\
Developed, Open Space (21) & 0.19 & 0.81 & 0 \\
Developed, Low Intensity (22) & 0.37 & 0.615 & 0.015 \\
Developed, Medium Intensity (23) & 0.45 & 0.51 & 0.04 \\
Developed, High Intensity (24) & 0.95 & 0.05 & 0 \\
Barren Land (Rock/Sand/Clay) (31) & 0.75 & 0.25 & 0 \\
Deciduous Forest (41) & 0 & 0.15 & 0.85 \\
Evergreen Forest (42) & 0 & 0.1 & 0.9 \\
Mixed Forest (43) & 0 & 0.2 & 0.8 \\
Scrub/Shrub (52) & 0 & 0.5 & 0.5 \\
Grassland/Herbaceous (71) & 0 & 0.9 & 0.1 \\
Pasture/Hay (81) & 0 & 1 & 0 \\
Cultivated Crops (82) & 0 & 1 & 0 \\
Woody Wetlands (90) & 0 & 0 & 1 \\
Emergent Herbaceous Wetlands (95) & 0 & 0 & 1 \\
\hline
\end{tabular}

${ }^{1}$ Class 31 is shown but not represented in the special contributing area zones. 


\section{Lake Michigan Diversion Accounting Land Cover Change Estimation}

\section{Raingage Network Partitioning Analysis}

A dense 25-raingage network covering the diverted Lake Michigan watershed was established in October 1989 and has been operated since then by the Illinois State Water Survey (ISWS) with funding from the USACE (Westcott, 2013). Hourly precipitation data from the network has been used by the USACE in LMDA HSPF models since then to determine total rainfall. For quality-control and security reasons, the weighing-bucket raingages have been located on private properties. Westcott (2013) provided complete site descriptions for each network location up to September 2011. Since the inception of the 25-raingage network, 15 sites have been relocated to different properties, and the coordinates have been provided by Westcott (private communication, Westcott, May 2014). With respect to placement, the period from October 1989 to February 2001 could be classified as the first generation of the 25-raingage network, and the placements after 2010 comprise the third generation of the 25-raingage network. Many of the relocations were near the original sites. Sites that had were moved more than a quarter mile include raingage numbers 2 , $6,9,11,19$, and 23; raingage 9 was moved the farthest (fig. 3).

The two upstream gaged basins, North Branch Chicago River at Niles and Little Calumet River at South Holland (including a portion of the Great Calumet River), required data from additional raingages outside of the ISWS network to cover the drainage areas. Several NCDC stations were selected and used in combination with the ISWS network for this purpose. The results are: 1) Little Calumet River watershed: ISWS network nos. 19, 22, 23, 24, and 25; NCDC stations Crete, Monee Reservoir, and Crown Point IN; 2) North Branch Chicago River: ISWS network nos. 1, 2 and 4 on the south portion and NCDC Waukegan on the north portion.

Note, however, that the Waukegan daily data ends in 2008. Missing daily data had been filled with daily records from two nearby Waukegan stations until 2011, and it was then disaggregated to hourly by using hourly patterns at either the USGS Gurnee raingage or the Chicago Waukegan airport raingage for the 1999-2011 period, and those at ISWS no. 1 for the period from 1995-99.

Modeling of runoff for the LMDA program requires that the rainfall values from the raingage network be assigned to the appropriate SCAs, upstream gaged basins, and ungaged basins. Raingage coverage areas are partitioned across the area through the use of Thiessen polygons. Thiessen polygons are a way to apportion raingage locations to unique areas such that any location within the area is closer to the area's raingage than to the raingage in any other area. Each area then defines an area of influence around its raingage, and the rainfall from that gage is used only in that area. Thiessen polygons were created for both the 1989 raingage network and the 2013 raingage network (fig. 3).

Thiessen polygons that intersect with LMDA areas create the basic modeling unit used in HSPF. Each unit is identified by the LMDA area and the raingage(s) that cover that area; for example, SCA zone M29 is covered by raingages 7 and 10, whereas the North Branch Chicago River upstream basin is covered by raingages $1,2,4$, and the NCDC Waukegan gage. By use of the processing steps described in the section "Conversion Weights for National Land Cover Dataset Classes," impervious, grass, and forest land acres and percentage of total area are calculated for each unique unit. The LMDA watershed, ungaged Lower Des Plaines basin, and Des Plaines SCAs that are described with the four NLCD datasets were further partitioned by using the 2013 raingage network. The results are included in tables $7-10$ and tables 12 and 13 of the downloadable Excel file provided at http://dx.doi.org/10.3133/ ofr20141258. A test was performed to partition the sewered SCA watersheds that are described with the NLCD 1992 and 2011 datasets with the 1989 raingage network (table 11). These two results are then compared to the RUST data (table 14) for examining the differences in the NLCD results and those used in the previous modeling work. The results are presented in table 16 (NLCD92 and raingage network 1989 compared to RUST data) and table 17 (NLCD11 and raingage network 2013 compared to RUST data).

\section{Assessment of Land Cover Types in the Drainage Area}

The total drainage area, percentages of Impervious/Grass/ Forest areas for two ungaged and four SCA basins that were determined by RUST and the USACE (2001), and those based on the modified NLCD92 data layer are shown in table 4. The data from RUST and the USACE (2001) are copied from table 3 of the technical report with the same format for ease of comparison. There are some small differences in total area for gaged Calumet and mainstream basins. The percentages of impervious area based on the NLCD92 are close to those revised by the USACE in 2001. The overall differences in impervious percentages are fairly small. The sources of differences could be the difference in land use classes that are based on the aerial photographs and NCLD92, and the conversion factors used.

Differences can also be attributed to the resolutions of the interpretation units used. RUST polygons were determined through planimetry on aerial photographs, thus allowing for delineation of fairly small polygons. Each unique land cover type that is visually detectable could be delineated. The NLCD, alternatively, has a fixed $30-\mathrm{m}^{2}$ pixel resolution, and each pixel is an interpreted land cover class. An unsupervised clustering algorithm assigns each distinct cluster to one of the NLCD classes. Land cover within the $30-\mathrm{m}^{2}$ area is not necessarily all the same class, but rather the majority class as interpreted by the algorithm. This is one reason that this study assigned forest lands in the gaged basins, in addition to the decision by RUST to assign tree cover to grass land. 


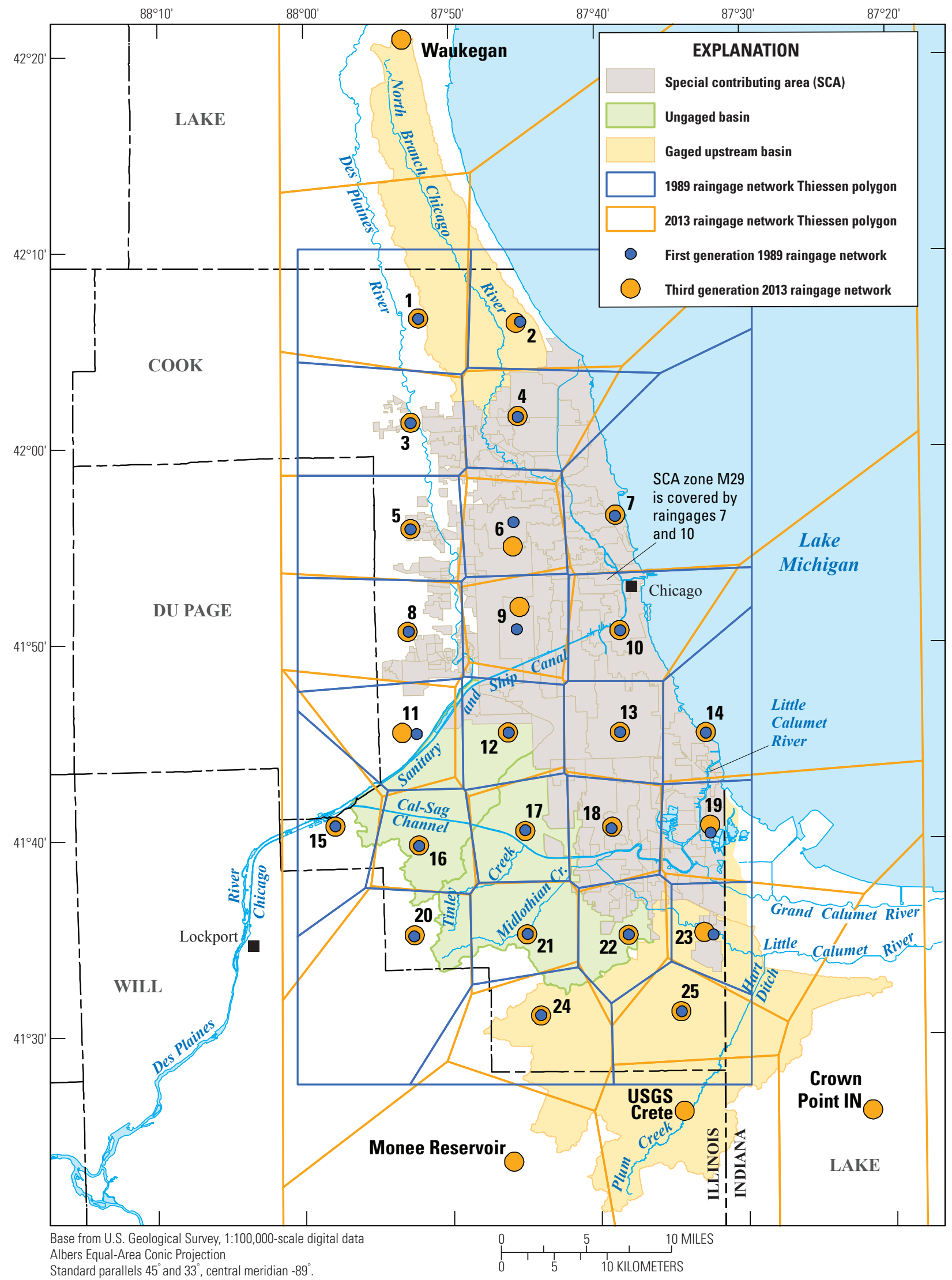

Figure 3. Location of the Lake Michigan Diversion Area raingage networks, northeastern Illinois. 
Table 4. Total basin area and percentage of impervious, grass, and forest areas determined by RUST Environment and Infrastructure (RUST, 1993), 1997 Soil Conservation Service TR-55 (U.S. Army Corps of Engineers, 2001), and National Land Cover Dataset (NLCD) 92 data.

[Rust Environment and Infrastructure: RUST; 1997 Soil Conservation Service TR-55: SCS-1997; National Land Cover Dataset 92: NLCD]

\begin{tabular}{lcccc}
\hline \multicolumn{1}{c}{ Basin } & $\begin{array}{c}\text { Basin area } \\
\text { (square miles) } \\
\text { RUST / NLCD }\end{array}$ & $\begin{array}{c}\text { Impervious } \\
\text { (percent) } \\
\text { RUST/SCS-1997/NLCD }\end{array}$ & $\begin{array}{c}\text { Grass } \\
\text { (percent) } \\
\text { RUST/SCS-1997/NLCD }\end{array}$ & $\begin{array}{c}\text { Forest } \\
\text { (percent) } \\
\text { RUST/SCS-1997/NLCD }\end{array}$ \\
\hline Ungaged Calumet & $84.2 / 84.2$ & $40.2 / 35.8 / 37.3$ & $54.3 / 58.7 / 48.0$ & $5.5 / 5.5 / 14.7$ \\
Ungaged Lower Des Plaines & $57.9 / 57.9$ & $33.3 / 30.1 / 31.4$ & $37.0 / 40.3 / 35.2$ & $29.7 / 29.7 / 33.4$ \\
\hline Calumet & & Gaged basins & & 0.0 \\
Des Plaines & $88.0 / 88.7$ & $54.2 / 50.4 / 50.3$ & $45.8 / 49.6 / 37.4$ & $0.0 / 12.4$ \\
Mainstream & $32.3 / 32.4$ & $55.6 / 48.6 / 46.9$ & $44.3 / 51.4 / 46.3$ & $0.0 / 6.8$ \\
Mainstream-North Leg & $205.7 / 204.1$ & $60.2 / 56.4 / 54.3$ & $39.1 / 43.6 / 39.9$ & $0.0 / 0.0 / 5.8$ \\
\hline
\end{tabular}

Table 5. National Land Cover Datasets 92, 01, 06, and 11 percentages of impervious, grass, and forest areas for ungaged, gaged, and upstream basins.

[LMDA, Lake Michigan Diversion Accounting; SCA, special contributing area; National Land Cover Dataset 1992: NLCD92; NLCD01: 01; NLCD 06: 06; NLCD 11:11]

\begin{tabular}{|c|c|c|c|c|}
\hline Basin & $\begin{array}{c}\text { Basin area } \\
\text { (square } \\
\text { miles) }\end{array}$ & $\begin{array}{c}\text { Impervious } \\
\text { (percent) } \\
\text { NLCD92 } 01|06| 11\end{array}$ & $\begin{array}{c}\text { Grass } \\
\text { (percent) } \\
\text { NLCD92 }|01| 06 \mid 11\end{array}$ & $\begin{array}{c}\begin{array}{c}\text { Forest } \\
\text { (percent) }\end{array} \\
\text { NLCD92 } 01|06| 11\end{array}$ \\
\hline \multicolumn{5}{|c|}{ Ungaged basins } \\
\hline Calumet & 84.2 & $37.3|37.7| 38.1 \mid 38.7$ & $48.0|52.9| 52.7 \mid 52.2$ & $14.7|9.4| 9.2 \mid 9.1$ \\
\hline Lower Des Plaines & 58.0 & $31.4|32.3| 32.5 \mid 33.1$ & $35.2|39.9| 39.9 \mid 40.0$ & $33.4|27.8| 27.6 \mid 26.9$ \\
\hline \multicolumn{5}{|c|}{ Gaged basins } \\
\hline Calumet & 88.7 & $50.3|46.8| 46.8 \mid 47.0$ & $37.4|48.2| 48.3 \mid 47.6$ & $12.4|4.9| 4.9 \mid 5.4$ \\
\hline Des Plaines & 32.3 & $46.9|46.6| 46.6 \mid 46.7$ & $46.3|50.8| 50.8 \mid 50.7$ & $6.8|2.6| 2.6 \mid 2.6$ \\
\hline Mainstream & 204.4 & $54.3|56.5| 56.5 \mid 57.1$ & $39.9|40.9| 40.9 \mid 40.3$ & $5.8|2.6| 2.6 \mid 2.6$ \\
\hline Mainstream-North Leg & 15.2 & 50.4 | 48.3 | $48.3 \mid 48.4$ & $43.7 \mid 48.5$ | 48.5 | 48.4 & $5.9|3.2| 3.2 \mid 3.2$ \\
\hline \multicolumn{5}{|c|}{ Upstream basins } \\
\hline North Branch & 91.0 & 30.6 | 31.4 | $31.9 \mid 32.8$ & 47.0 | 54.5 | 54.8 | 54.2 & $22.4|14.1| 13.4 \mid 13.0$ \\
\hline Calumet & 188.1 & $22.3|24.2| 25.6 \mid 26.8$ & $58.7|59.9| 59.2 \mid 58.5$ & $19.0|16.0| 15.1 \mid 14.7$ \\
\hline $\begin{array}{l}\text { Gaged North Branch } \\
\text { Chicago River and } \\
\text { Calumet basin }\end{array}$ & 279 & $25.0|26.5| 27.7 \mid 28.8$ & $54.9|58.1| 57.8 \mid 57.1$ & $20.1|15.4| 14.5 \mid 14.1$ \\
\hline HSPF-modeled LMDA basin ${ }^{1}$ & 393 & $49.6|50.0| 50.0 \mid 50.6$ & $41.2|45.4| 45.4 \mid 44.8$ & $9.2|4.6| 4.6 \mid 4.6$ \\
\hline Entire diversion basin ${ }^{2}$ & 672 & $39.4|40.2| 40.7 \mid 41.5$ & 46.9 | $50.7 \mid 50.5$ | 49.9 & $13.7|9.1| 8.7 \mid 8.6$ \\
\hline
\end{tabular}

\footnotetext{
${ }^{1}$ The HSPF-modeled LMDA basin includes: Ungaged Calumet, Calumet SCA, Mainstream SCA, Mainstream-North Leg SCA.

${ }^{2}$ The entire diversion basin is the sum of Ungaged Calumet, Calumet SCA, Mainstream SCA,Mainstream-North Leg SCA, Gaged North Branch Chicago River at Niles, and Little Calumet at South Holland.
} 


\section{Results of Land Cover and Raingage Segmentation}

The results of the segmentation of land cover for the LMDA areas and raingage network, the segmentation of NLCD92 to the 1989 ISWS raingage network, and the segmentation of NLCD11 and the 2013 ISWS raingage network are presented in tables 5-20. The tabulation format follows those presented by RUST (1993).

\section{Data Table Description}

Tables 5-20 are presented in a Microsoft Excel file available at http://dx.doi.org/10.3133/ofr20141258. A description of each table follows:

ReadMe: Description of the tables.

Table 5-Basin Statistics: Total impervious, grass, and forest land for the four NLCD versions for the SCA, ungaged basins, and upstream basin. [Repeat of table 5 from this report.]

Table 6-Conversion Weights: The NLCD has 16 classes, which were converted to LMDA impervious, grass, and forest land by a weight matrix designed for this study. Also included in this table are the RUST and the TR-55 conversion weights.

Tables 7-10-NLCD92/01/06/11 Partitioning: NLCDderived land covers are partitioned by the 2013 raingage network. Includes areas for SCA, ungaged basins (Lower Des Plaines and Calumet), and gaged basins (North Branch Chicago River above Niles, Little Calumet at South Holland, and Grand Calumet). Columns $A-D$ : SCA zone identifier information, ungaged area descriptor, and upstream watershed descriptor; columns $E-T$ : NLCD classes reported in acres $(\mathrm{E}-\mathrm{S})$, followed by the total acres (T); columns $U-W$ : Impervious, grass, and forest acres; columns $X-Z$ : Impervious, grass, and forest percentage of basin; columns $A B-A C$ : SCA zone information for reference; columns $A E-A J$ (repeated through column $\mathrm{BB}$ for each raingage partition; gages may have results for up to four raingages): Raingage partition information, including raingage identifier, acres within the raingage partition, percentage of area covered by the raingage, impervious acres, grass acres, and forest acres; columns $B D-B E$ : SCA zone information for reference; columns $B G-B L$ (repeated through column $\mathrm{CD}$ for each raingage partition, gages may have results for up to four raingages): Raingage partition information, including raingage identifier, square miles within the raingage partition, percentage of area covered by the raingage, impervious square miles, grass square miles, and forest square miles.

Table 11-NLCD92 with 1989 RGs: NLCD92 partitioned to the 1989 raingage network. Same information as provided in Columns AE-AJ in table 7.

Table 12-Ungaged Basin RG Stats: NLCD statistics and impervious, grass, and forest statistics as a result of applying the conversion weights to NLCD92, NLCD01, NLCD06, and NLCD11 for the ungaged basins partitioned by the 2013 raingage network.

Table 13-Gaged Basin RG Stats: NLCD land cover and impervious, grass, and forest statistics as a result of applying the conversion weights to NLCD92, NLCD01, NLCD06, and NLCD11 for the two upstream gaged basins partitioned by the 2013 raingage network.

Table 14-RUST Data: Original RUST table from the 1993 study. Layout is similar to that presented in tables 7-10.

Table 15-RUST SCA Statistics: SCA impervious, grass, and forest acres using the RUST weights from the 1993 study.

Table 16-RUST vs. NLCD92\&89 RGs: A comparison between impervious and grass from the 1993 RUST study and NLCD92 using the 1989 raingage network.

Table 17-RUST vs. NLCD11\&13 RG: A comparison between impervious and grass from the 1993 RUST study and NLCD11 using the 2013 raingage network.

Table 18-NLCD Charts: Charts presenting A) the percentages of impervious, grass, and forest for NLCD92 through 11, and B) the percentages of all classes for NLCD92 through 11 .

Table 19-NLCD\%Difference Charts: The percentage of difference in grass, forest, and impervious in the four NLCD versions are shown.

Table 20—92,01,06,11_Comparison: Differences between the acres for each SCA zone and NLCD combinations. These computations are needed for the charts presented in tables 18 and 19. 


\section{Summary}

Acreages for the three land covers determined by using the National Land Cover Dataset (NLCD), and the conversion weights compared favorably for gaged and ungaged basins of the diverted Lake Michigan watershed with the land covers and conversion weights previously determined by RUST Environment and Infrastructure (1993) and the U.S. Army Corps of Engineers (USACE; 2001). This study also developed an automated process for defining the three land cover types, thereby allowing faster updating for future models, and for the evaluation of land cover changes by using historical National Land Cover Dataset (NLCD) datasets.

For the Lake Michigan Diversion Accounting (LMDA) basin modeled by using the Hydrological Simulation Program-FORTRAN (HSPF), the impervious area remains almost constant for 20 years (1992 through 2011) at about 50\%, with about $5 \%$ decreases in forest land but $5 \%$ increases in grass land in the first 10 years (1992-2001); probably due to the definition of land uses used in the 1992 and 2001 datasets. The percentages of forest land and grass land during 2001, 2006, and 2011 are more consistent. For the entire LMDA diversion basin, the impervious area changed slightly from $39.4 \%$ in 1992 to $41.5 \%$ in 2011, and the grass land area remained about $50 \%$, with an approximation of $5 \%$ forest land to grass land interpretation difference during the 1992-2001 period. With these realizations, it is apparent that higher increases in impervious area occurred in the two gaged upstream basins than in the ungaged Calumet basin and all SCA areas. Impervious areas in the two gaged upstream basins increased from $25 \%$ in 1992 to $28.8 \%$ in 2011 , with grass land about $57 \%$ and forest land about $14 \%$ (table 5). The land cover remains static in the second 10 years (2001-11). In the LMDA hydrologic model in current (2014) use, no forest land cover is designated for any special contributing area (SCA); the forest land cover is generally included in grass land cover. The land cover changes for impervious area in the HSPF-modeled LMDA basis are very small.

\section{References Cited}

Donigian, A.S., Imhoff, J.C., Bicknell, B.R., and Kittle, J.L., 1984, Application guide for Hydrologic Simulation Program-Fortran (HSPF): Athens, Georgia, U.S. Environmental Protection Agency-600/3-84-065, Environmental Research Laboratory, 177 p.

Hill, L., 2007, The Chicago River: A natural and unnatural history: Chicago, Lake Claremont Press, 302 p.

RUST Environment and Infrastructure, 1993, Diversion accounting update for the new 25-gage precipitation network, submitted to the U.S. Army Corps of Engineers, Chicago District, October 1993, 5 p. with 6 appendixes.

Soil Conservation Service, 1986, Urban hydrology for small watersheds, TR-55: U.S. Department of Agriculture, Soil Conservation Service, Technical Release 55, variously paginated.

U.S. Army Corps of Engineers, Chicago District, 1981, Lake Michigan Diversion: Findings of the Technical Committee for Review of Diversion Flow Measurements and Accounting Procedures: Final report: 110 p.

U.S. Army Corps of Engineers, Chicago District, 2001, Lake Michigan Diversion Accounting annual report water year 1998. [Appendix A: WY97 Lake Michigan Diversion Accounting Report].

U.S. Army Corps of Engineers, Chicago District, 2004, Lake Michigan Diversion: Findings of the Fifth Technical Committee for Review of Diversion Flow Measurements and Accounting Procedures: Final Report, 181 p.

U.S. Army Corps of Engineers, Chicago District, 2009, Lake Michigan Diversion: Findings of the Sixth Technical Committee for Review of Diversion Flow Measurements and Accounting Procedures: Final Report, 198 p.

U.S. Army Corps of Engineers, Chicago District, 2014, Lake Michigan Diversion: Findings of the Seventh Technical Committee for Review of Diversion Flow Measurements and Accounting Procedures: Final Report, 152 p.

Westcott, N.E., 2013, Continued operation of a 25-raingage network for collection, reduction, and analysis of precipitation data for Lake Michigan diversion accounting: Water year 2012: Illinois State Water Survey, Prairie Research Institute, University of Illinois at Urbana-Champaign, Contract Report 2013-01, 81 p. 



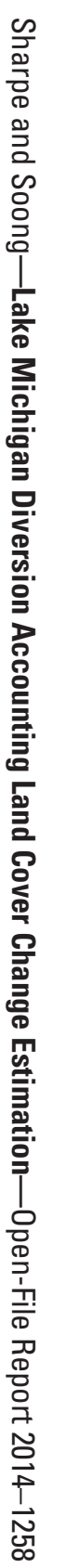

